\title{
И.В. Зайщев
}

\section{К истории библиотеки московских имамов Агеевых}

История ислама в Москве вплоть до начала XX в. крайне скудна оригинальными текстами. Для воссоздания отдельных ее аспектов исследователи пользовались, как правило, материалами на русском языке (это архивные источники, законодательство, статистика, источники мемуарного характера) ${ }^{1}$. Пожалуй, одним из немногих текстов, касавшихся московской общины и вышедших из-под пера московских мусульман, который оказался отраженным в научной литературе, стала расписка московского имама Рафика Агеева о произведенном бракосочетании на обороте «Векялет-наме»² от 19 октября 1837 г. [ЦИАМ. Ф. 2200. Оп. 1. Д. 1 (Метрическая книга Московской мечети). Л. 33 и 33об], опубликованная в виде факсимиле [Хайретдинов, 2002, с. 233-236].

В 2008 г. было предпринято издание энциклопедического словаря «Ислам в Москве» [Ислам, 2008], который наглядно показал, что, несмотря на очевидные успехи «исламского москвоведения», наши знания об истории этой мировой религии в столице России все еще весьма скромны и приблизительны. Еще меньше нам было известно об уровне образованности московских мусульман, книжном и рукописном деле, собирательской деятельности и исламских библиотеках города.

В 1805 г. оренбургский муфтий Мухаммеджан Хусаинов лично обратился к московскому военному губернатору А.А. Беклешеву с ходатайством о возведении каменной мечети в московской Татарской слободе, объясняя необходимость этого многочисленностью приезжающих в город мусульман (ежегодно от 250 до 300 торговцев и гостей). Сама слобода к тому времени насчитывала 12 домов и 57 и 45 душ мужского и женского пола соответственно. Однако на основании жалобы причта Замоскворецкой церкви великомученика Никиты новый московский генерал-губернатор князь Д. Голицын 28 сентября 1823 г. предписал уведомить мусульман о том, чтобы азан в Татарской слободе не производился. Одновременно в качестве компенсации за запрет,

1 | Интересующихся темой отсылаю к ряду статей Ал. Маслова «Древние урочища Замоскворечья: Крымский двор», «Крымский брод», «Крымский луг» [Маслов, 1992, 1993а, 19936], монографиям Ф.А. Асадуллина [Асадуллин, 2004] и Д.3. Хайретдинова [Хайретдинов, 2002]. См. также мою рецензию на последнюю книгу: [Зайцев, 2004], и мои собственные статьи [Зайцев, 2005, 2006]. 2 | В данном случае это доверенность в выдаче замуж. 
купцу «из бухарцев» Назарбаю Хашалову ${ }^{3}$ разрешалось производить богослужение, не называя помещение молитвенного собрания мечетью [Загидуллин, 2007, с. 333].

В 1880 г. старший ахун Хайретдин Агеев и староста молитвенного дома Ибрагим Девишев представили план реконструкции (расширения) молитвенного дома (мечети) архитектора Д.И. Певницкого [Там же. С. 334] ${ }^{4}$. В следующем году она была перестроена, возведены минарет и купол, и в 1882 г. мечеть приобрела вид традиционного культового исламского здания.

Молитвенные собрания в мечети вплоть до 1913 г. проводились ахунами из рода Агеевых 5 . В литературе встречается мнение, что эта семья была родом из Сибири [Асадуллин, 2004, с. 81] ${ }^{6}$, однако в действительности, как будет показано ниже, происходили Агеевы из Казани. Казанское происхождение Агеевых косвенно подтверждается их родственными связями. Видный татарский общественный и религиозный деятель Габдеррашид Ибрагимов вскользь упоминает о своей встрече в 1879 г. в Одессе в доме муллы Ибрагима Адигаева с неким Ахмедом Нэрми (в османских документах он упоминается как احمد نرمى) и при этом называет его родственником московского муллы Хайретдина. Безусловно, под последним имеется в виду Хайретдин Агеев. Нэрми подобно самому Ибрагимову намеревался покинуть Россию без паспорта, нелегально, что ему в конце концов и удалось. «Сведения о предыдущей и последующей биографии Нэрми содержатся в одном из томов Реестра государственных служащих Османской империи. Согласно сведениям этого документа, хранящегося в Османском архиве, Ахмед Нэрми родился в 1277/1860-61 г. в Москве, в семье “казанского жителя и улема" Нурутдина и является “одним из казанских мухаджиров”. По окончании Султанской школы гражданско-административной службы ... [Нэрми. - И. 3.] поступил на государственную службу». К 1891 г. он совмещал должности преподавателя русского языка в Султанской школе военных наук и переводчика службы цивильного листа при султанском дворе [Мустакимов, 2008, с. 24].

Рафик б. Бекбулат Агеев стал муллой в 1817 г., а имамом Московской мечети - в 1833 г. (возглавлял Историческую мечеть вплоть до 1867/68 гг.). Судя по тому, что к имени имама добавлялась почетная приставка «хаджи», Рафик Агеев совершил хаджж. Умер имам в

3 | В литературе можно встретить написание Хамалов (видимо, правильный вариант фамилии). Кроме того, часто указывалось, что он был купцом первой гильдии.

4 | Дмитрий Иванович Певницкий (ок. 1825 - 1887) - архитектор Пятницкой части Москвы с 1880 г.

5 | Агеевы - достаточно распространенная татарская фамилия. Так, печать некоего И.Б. Агеева (возможно, родственника московских Агеевых) стоит на рукописном экземпляре Хуласат ал-хисаб фи илм ал-хисаб («Сущность арифметики»), переписанной в 1871 г. и привезенной в Казань из Касимовской археографической экспедиции 1964 г. [Идеатуллин, 1987, с. 30]. Некий офицерпрапорщик татарин «Аггеев» летом 1917 г. служил в Спасском полку Юго-Западного фронта и вел там разъяснительную работу среди солдат-мусульман в связи с выборами в Учредительное собрание [Исхаков, 2004, с. 224]. Первый профессиональный татарский детский писатель также носил фамилию Агеев [Назаров, 2009].

6 | Впервые об этом написал московский журналист М. Третьяков, побывавший в мечети в 1901 г. По воспоминаниям же потомков рода, Агеевы были пензенскими или тамбовскими мишарями [Хайретдинов, 2008, с. 7]. 
1873 г. [Асадуллин, 2004, с. 57; Хайретдинов, 2008, с. 8]. Официально должность Рафика именовалась «Татарской слободы соборный имам мухтасип и мударес мулла Рафек Агеев»; он подписывался также «ахун и соборный мулла-мухтасиб, мударрис». Исходя из этих званий, становится ясно, что иерархически московский имам подчинялся муфтию в Уфе, а московские мусульмане составляли отдельный мухтасибат в рамках Оренбургского магометанского духовного собрания. Кроме того, очевидно, что Агеев преподавал в медресе при Московской мечети. В его обязанности входила также и работа с военнослужащимимусульманами из московских воинских частей.

Следующим имамом (с конца 60-х гг. XIX в.) стал его сын, выпускник Апанаевского медресе в Казани Хайретдин хаджи Агеев «московский гражданский и военный имам», почетный гражданин Москвы, умерший в 1913 г. на 86-м году жизни (род. ок. 1827 г.) [Хайретдинов, 2002, с. 121, 126, 209]7. Рафик б. Бекбулат и его сын Хайретдин проживали в Татарской слободе Москвы (на Б. Татарской улице в двух домах напротив Татарского и Кузнецкого переулков). В справочнике «Вся Москва» за 1901 г. (с. 5) Хайредтин Рафиков «Аггеев» указан живущим на Б. Татарской в собственном доме. Там же указан и Мухаммед Зайнуллович «Аггеев» (Б. Татарская, дом Исакова) - муэдзин мечети.

Хайретдин Агеев личность в истории московской мусульманской общины выдающаяся. По данным Д.З. Хайретдинова, он владел восемью восточными и европейскими языками. Пожалуй, лучше всего Хайретдин Агеев охарактеризован Ф.А. Асадуллиным: «Знаток нескольких восточных и европейских языков, человек высокой образованности не только в исламских, но и в гуманитарных науках, Хайретдин Агеев оставил заметный след в научной и культурной жизни Москвы конца XIX - начала XX в. Не прерывая духовно-проповеднической деятельности в Соборной мечети, он преподавал основы исламского вероучения в медресе и военных учебных заведениях Москвы, где учились мусульмане, состоял переводчиком при Оружейной палате, оставив после себя описания памятников средневековой мусульманской материальной культуры. Например, ему принадлежит авторство перевода стихов персидского поэта Гассана-Кази на “зульфикаре" - двухконечном мече Али, четвертого праведного халифа: "Нет храбрее, чем Али, нет меча, кроме Зульфикара”, — который поступил в Оружейную палату в 1810 г. Во время посещения Москвы иранским монархом Насер ад-Дин-шахом, ахун Хайретдин Агеев сопровождал его и давал объяснения во время осмотра экспонатов палаты. При его активном участии в качестве одного из консультантов было осуществлено последнее издание русского перевода Корана, выполненного К. Николаевым. Перевод Николаева, имевший бесспорные литературные достоинства, был выполнен не с оригинала, а с французского перевода, что потребовало от Хайрет-

7 | 0 военных имамах и круге их должностных обязанностей см.: [Абдуллин , 2005, с. 225-230]. 
дина Агеева значительных усилий для исправления многих смысловых неточностей. К мнению просвещенного ахуна проявляли интерес многие ученые-востоковеды, царские чиновники, занимавшиеся жизнью мусульманских народов, ...» [Асадуллин, 2004, с. 81]. К величайшему сожалению, сам шах Насер ад-Дин, который оставил довольно подробное изложение своего первого путешествия по Европе в 1873 г., описал и визит в Оружейную палату Московского Кремля, однако не счел нужным упомянуть о сопровождавшем его там московском имаме... [Насир ад-Дин, 1377, с. 45].

Действительно, Х. Агеев много сделал для описания восточных коллекций Оружейной палаты. Об этом свидетельствует докладная записка директору палаты А.Ф. Вельтману от Хайретдина Агеева, датированная сентябрем 1868 г., с просьбой о вознаграждении его Тарханским достоинством за труды по переводу восточных текстов в собрании Оружейной палаты в 1863-1866 гг. [Зайцев, 2010].

Потомки семьи продолжали служение при Исторической мечети и в советское время. «Благодаря стараниям муэдзина Мухамметкарима Агеева, скорее всего связанного родственными узами с известной семьей имамов, во дворе мечети были построены солнечные часы в виде каменного столба, по которым можно было точно определить время намаза». Этот поступок вызвал одобрение Галимджана Баруди (18571921), тогда муфтия Духовного управления мусульман Внутренней России и Сибири: «Дело ведь не только в том, чтобы призвать к молитве, нужно точно определить ее время, - замечает Г. Баруди. Быть муэдзином, несведущим в вопросах религии, необразованным, не знающим молитв, алчным, как некоторые казанские муэдзины, большое бесстыдство и нечестность. Хотя Москва - непросвещенное место, мусульман в ней немного, этот муэдзин постарался хорошо выполнить свою обязанность...» [Цит по: Асадуллин, 2004, с. 108].

Мечеть была закрыта в 1937 г. после расстрела последнего ее имама Абдуллы Шамсутдинова - родственника Агеевых (он был женат на дочери Хайретдина Агеева - Магире) [Хайретдинов, 2008, с. 9]. Позднее часть семьи переселилась в Узбекистан (устное сообщение Р. Шигабдинова автору), где до недавнего времени проживали потомки московских Агеевых.

Таким образом, более ста лет духовными лидерами московских мусульман были представители одной семьи. Естественно, что многообразная религиозная, общественная и научная деятельность Агеевых предполагала наличие богатой семейной библиотеки, которая, вероятно, была по преимуществу рукописной. К счастью, ее часть дошла до нас. Большое количество рукописей, принадлежавших семье, хранится ныне в собрании библиотеки Московского государственного института международных отношений (Университет) МИД РФ, а также в фондах Отдела рукописей Российской государственной библиотеки. Одна, безусловно агеевская, рукопись найдена мною в Институте восточных 
рукописей РАН в Санкт-Петербурге ${ }^{8}$. Основные признаки, которые выделяют агеевские рукописи, - владельческие записи, пометки и печати членов семьи. Перечислим известные к настоящему времени рукописи семейного собрания Агеевых 9

1. Абу-л-Хасан Али ал-Вахиди ан-Найсабури (ум. в 468/1075 г.) « "تفسير القرآن الوجيز ". (МГИМО, № 7). Комментарий к Корану10. Плотная восточная бумага без филиграней. Размер $18 \times 25,3$ см (блок толщиной 4,5 cм), по 27 строк на странице (есть и по 26, и по 28). Почерк насx. Чернила коричневатые и красные. Текст без рамки. Колофон на л. 183 дает дату переписки рукописи - Шабан 729 г.х. (июнь 1329 г.). Переписчик Сулейман б. Абдаллах б. Сулейман б. Аби аз-Зикр. На форзаце владельческая запись «Хайреддина сына покойного хаджи муллы Рафика Агеева ал-Москови» ${ }^{11}$.

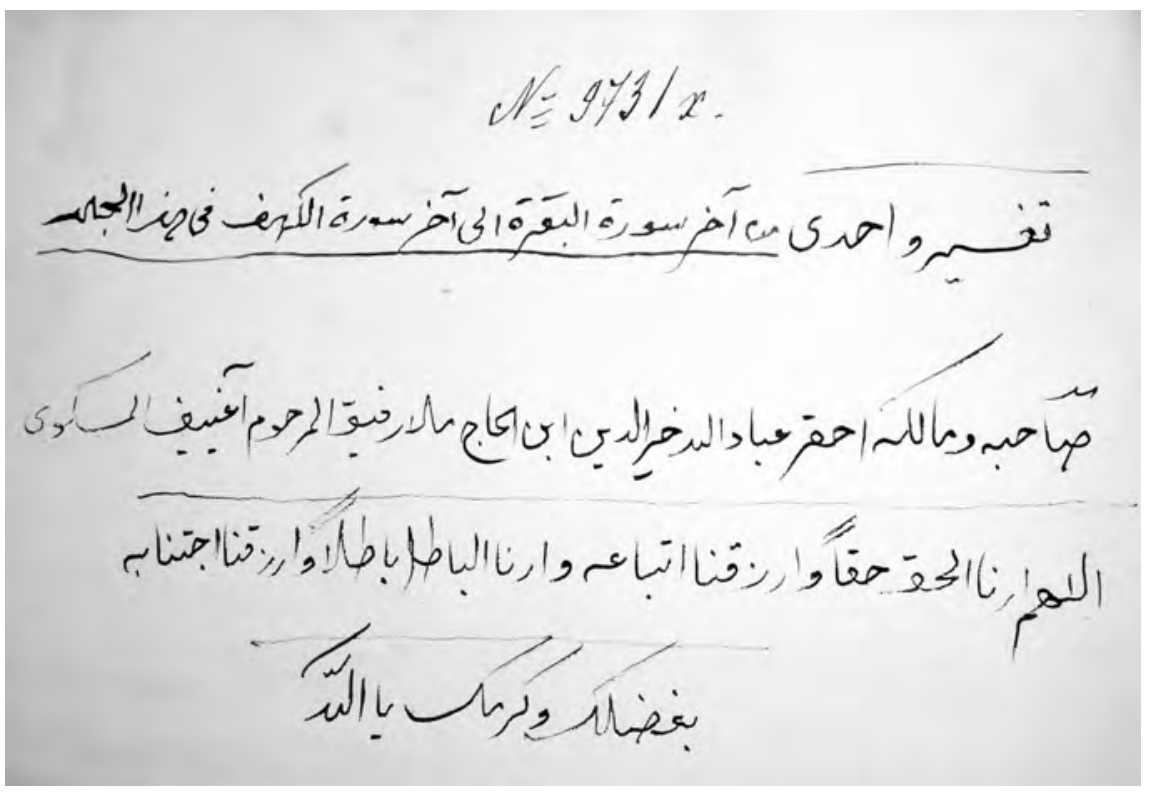

2. Мухаммад ал-Бахарзи. Комментарий к комментарию Ахмада б. Муса ал-Хайали (после 1458 г.) [ИВР № 1422-1462] к комментарию ат-Тафтазани (1322-1390 гг.) [ИВР № 1376-1421] к «ал-Акаид ан-Насафийа» Омара б. Мухаммада ан-Насафи (1142 г.) [ИВР № $1342-$ 1592]. (МГИМО № 11; старый лазаревский № 9740x на л. 1). Т. 1. По-

8 | Я чрезвычайно признателен заведующей библиотекой МГИМО(У) МИД М.В. Решетниковой, а также В.Ф. Молчанову, 0.Л. Соломиной (ОР РГБ) и И.Ф. Поповой (ИВР РАН) за возможность ознакомиться с соответствующими коллекциями.

9 | Для рукописей МГИМО в качестве шифра дается их порядковый номер по машинописному каталогу. Отождествление арабских текстов из собрания МГИМО произведено Д.И. Морозовым при описании коллекции.

10 | Списки см.: [ИВР № 408-410].

11 Рукопись экспонировалась на выставке «Исламская рукописная книга из московских собраний» (Государственный исторический музей, 17 августа - 20 сентября 2004 г.). Каталог см.: [Зайцев, 2004а, с. 11, № 6, ил. на с. 51]. 
волжье, XVIII в. Форзац оклеен цветной бумагой, переплет кожаный $(17 \times 21,5$ cм), поверх наклеена потертая синяя бумага с красными пятнами (обои?). Корешок утрачен. Бумага русская (крест с короной в овале и буквы ТФСТ). На л. 2 печать Зайн ад-дина Рафикова. Чернила коричневые (заголовки и отдельные слова красными), почерк насх с небольшим наклоном вправо, $x a \oint u з ы, ~ 17$ строк на странице. На л. 180 печать ИВ НКП РСФСР № 09/107681. Задняя крышка отстает. На л. 179об. сохранилась владельческая надпись Хайретдина сына муллы Рафика ал-Булгари. Между л. 114 и 115 оказалась вложенной записка на клочке бумаги с русским текстом в старой орфографии:

«В татарской улице замаскварецким мисгит(ь)

\section{Записка}

Господину дьякану. Прашу прибыть для похоронения ва вторник байгуша ${ }^{12}$ извещаю прапорщик Буханов

Хоронил тело умершаго Диакон Хаасан Абдул Карамичь Муслимова

Генваря 21го дня 1834 года».

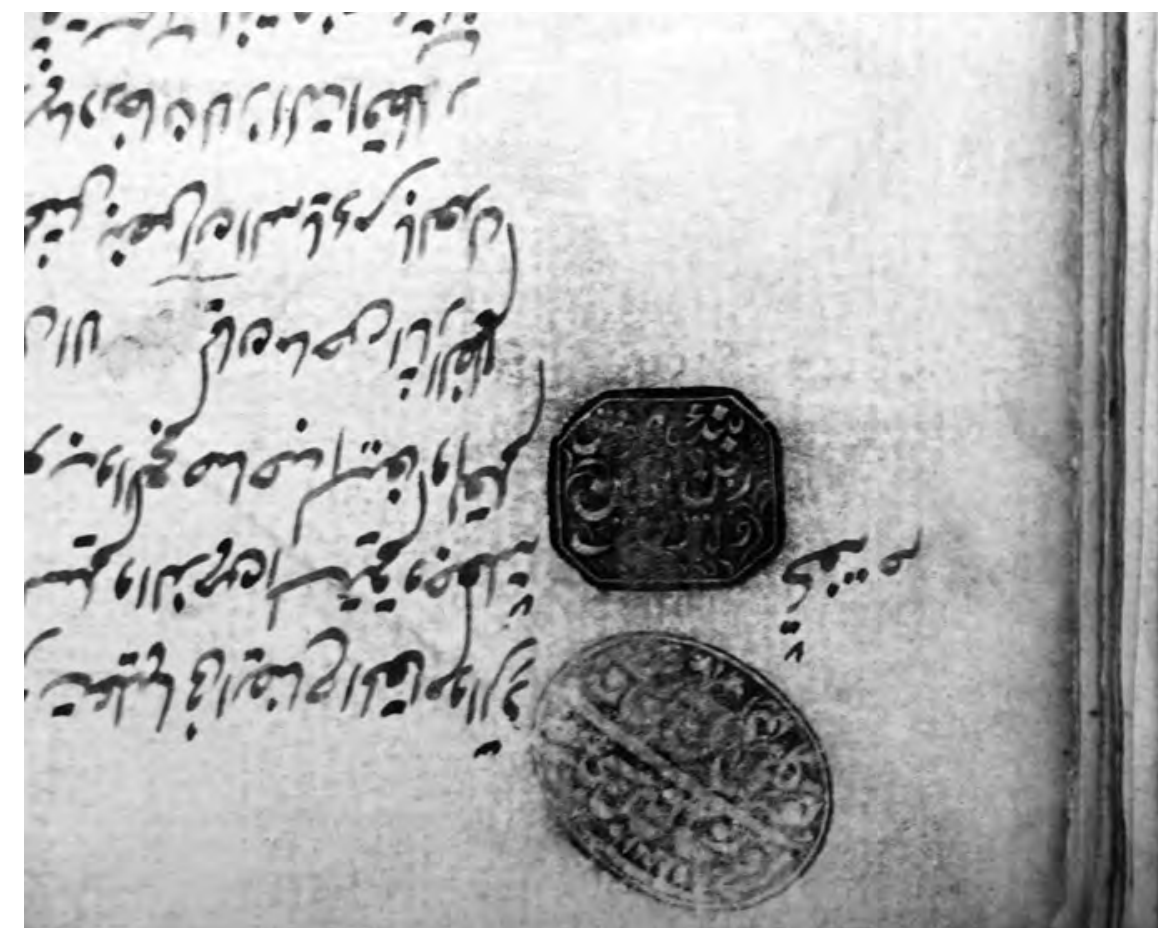

12 | Байгуш - собственно, «безлошадный»; слово вошло в русский язык и зафиксировано в Толковом словаре живого великорусского языка В.И. Даля в значении «обнищавший инородец, нищий» (оренбургское). 


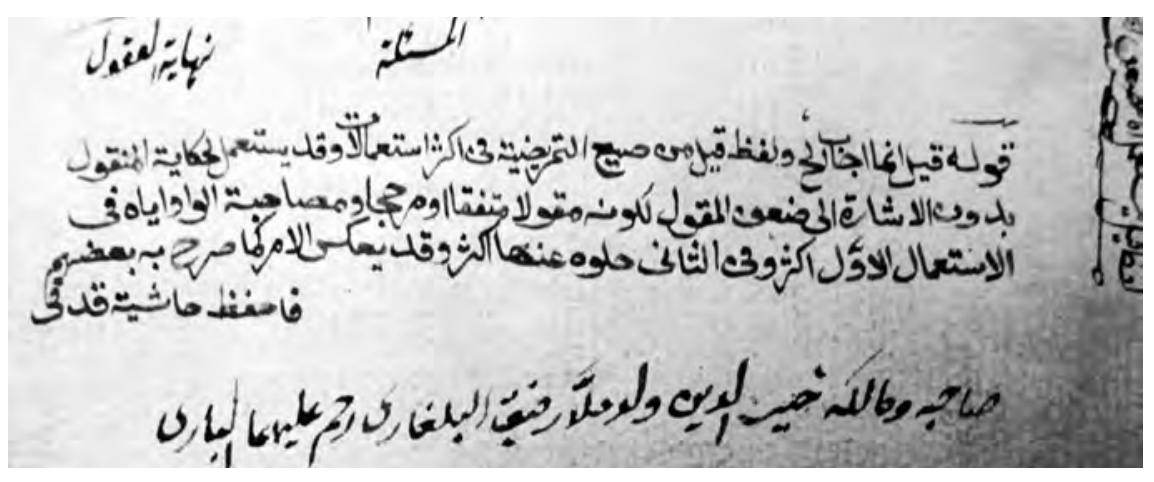

3. Правила совершения молитв на арабском (МГИМО № 25). 1852 г. Пометки на татарском. Тетрадка $(11 \times 18$ см) без переплета. 8 листов. Между листами 5 и 6 вложен листок с басмалой и несколькими пометами и оттиском крупной восточной печати с именем Мухаммад Карим б. Зайн ад-Дин ${ }^{13}$ и датой 1278 г.х. (1861-62 гг.). На обложке очень коряво по-русски попытки написать адрес: в г. Москве но Тоторской улиц въ Дом Агееву (далее несовсем разборчиво Мо(с)ква?). Чернила коричневые, почерк насх, 12-13 строк на странице, хафизы. На л. 7 колофон на татарском, согласно которому текст был переписан 2 октября 1852 г.

4. Бурхан ад-Дин Махмуд б. Садр аш-Шариа (ок. 1281 г.) «Викайат ар-ривайа фи масаил ал-Хидайа» (МГИМО № 30), списки см: [ИВР № 3967-74]. Бумажный переплет без корешка подплетен позднее. Формат $17 \times 25,5$ см. Бумага русская (филиграни с датой 1820 г.). Лазаревский № 9732х; на л. 1 печать МГИМО 1948 г.; на л. 142об. печать НБ ИВ НКП РСФСР № 09/112288. Чернила черные, насх (иногда сбивается на талик с наклоном вправо), по 15 строк на странице, заголовки красным. Текст без рамки, площадь примерно 10×18 см, хафизы. По поздней карандашной нумерации 142 листа. На л. 1 коричневыми чернилами насхом выполнена владельческая надпись о том, что эта книга принадлежит Зайн ад-дину сыну муллы Рафика ал-Булгари. На полях нередко пометы, подчеркивания в тексте - красным. Между л. 83 и 84 оказались вложенными 2 клочка (первый — на татарском с правилами совершения молитв и азана; второй со стихами, 1 айатом из Корана и пословицей).

5. Маулана мулла Садик (Мухаммад Садик XVI в.?). Комментарий к комментарию ал-Кати (1359 г.) [ИВР № 5340-5405] к «Исагуджи» [ИВР № 5322-5339] — обработке «Введения» Порфирия (VI в.) к «Логике» Аристотеля, принадлежащей Асир ад-Дину ал-Абхари (1265 г.) [списки см: ИВР № 5414-5426] МГИМО № 38, старый лазаревский № 9742x. На форзаце надпись:

13 | Видимо, внук Рафика Агеева. Муэдзин Исторической мечети (упомянут в этом качестве в 1891 и 1915 гг.) и ее фактический руководитель в годы Гражданской войны [Хайретдинов, 2008, с. 9]. 


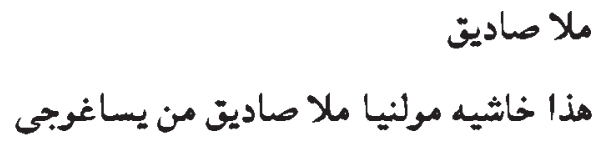

На форзаце печати МГИМО (1948 и 1954 гг.), а также надпись:

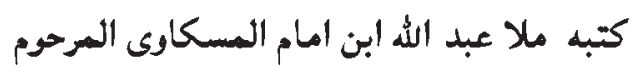

Европейский картонный переплет, оклеенный синей бумагой (17×21,5 cм). Корешок (кожаный) отсутствует. На верхней крышке под своего рода тугрой заглавие рукописи. 128 листов, почерк насх (с элементами талика), коричневые чернила, бумага русская (штемпель). Отдельные слова и подчеркивания — красными. Текст без рамки (примерно 7,5×15 см), кончается на л. 123. Хафизы. На полях пометки красными чернилами. Поздняя карандашная нумерация с пропусками (напр., лист между л. 71 и 72 не нумерован). Между л. 93 и 94 лист вырезан. На его месте оказался листок с текстом на тюрки на одной стороне и фрагментом письма с образцами подписи (в том числе и по-русски Агеевъ) - на другой:

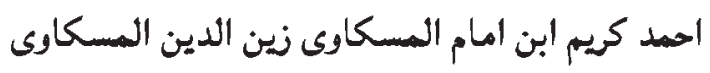

В последнем случае в нисбе ал-Маскави вав написан с характерными тремя точками над харфом.

6. Табир-наме (تعبير نامه ) Тюркская (МГИМО № 269).

Переплет красной кожи, 18×22,2 см, крышки с тиснением (угольники и по серединам сторон), турундж со спутниками. Бумага русская, листы 1-4 чистые. На л. 1 чернилами старым дореволюционным почерком и орфографией краткое описание и номер 9736x (вероятно, Лазаревский). На л. 5 в верхнем левом углу черными чернилами надпись в 4 строки (рядом печать научной библиотеки МГИМО и смазанный оттиск восточной печати:

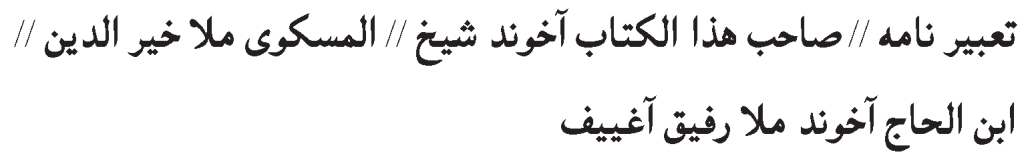

Начало после басмалы, почерк размашистый насх с элементами талика, наклон вправо. Чернила черные, заголовки - красными, ха$\oint u з ы, ~ 15$ строк на странице. Текст в красной рамке $13 \times 16$ см. Согласно колофону на л. 79, переписчик манускрипта - некий Мухаммад Хасан б. Муртаза, дата переписки - 1839 г. Там же пометка Муллы Хайр адДина Агеева 1891 г.

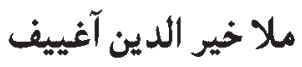

Листы 80-82 чистые. На л. 79об. печать ИВ НКП РСФСР с номером 09/107663. Сочинение это, судя по incipit, полностью идентично 
рукописи ИВР РАН — (шифр В2832) анонимному сочинению — толкованию снов без названия, переписанному в Поволжье не позже 1871 г., и принадлежавшему 'Абд ал-Хакиму б. Халиду, а потом Х.Х. Бакирову [Дмитриева, 2002, с. 524, № 2293].
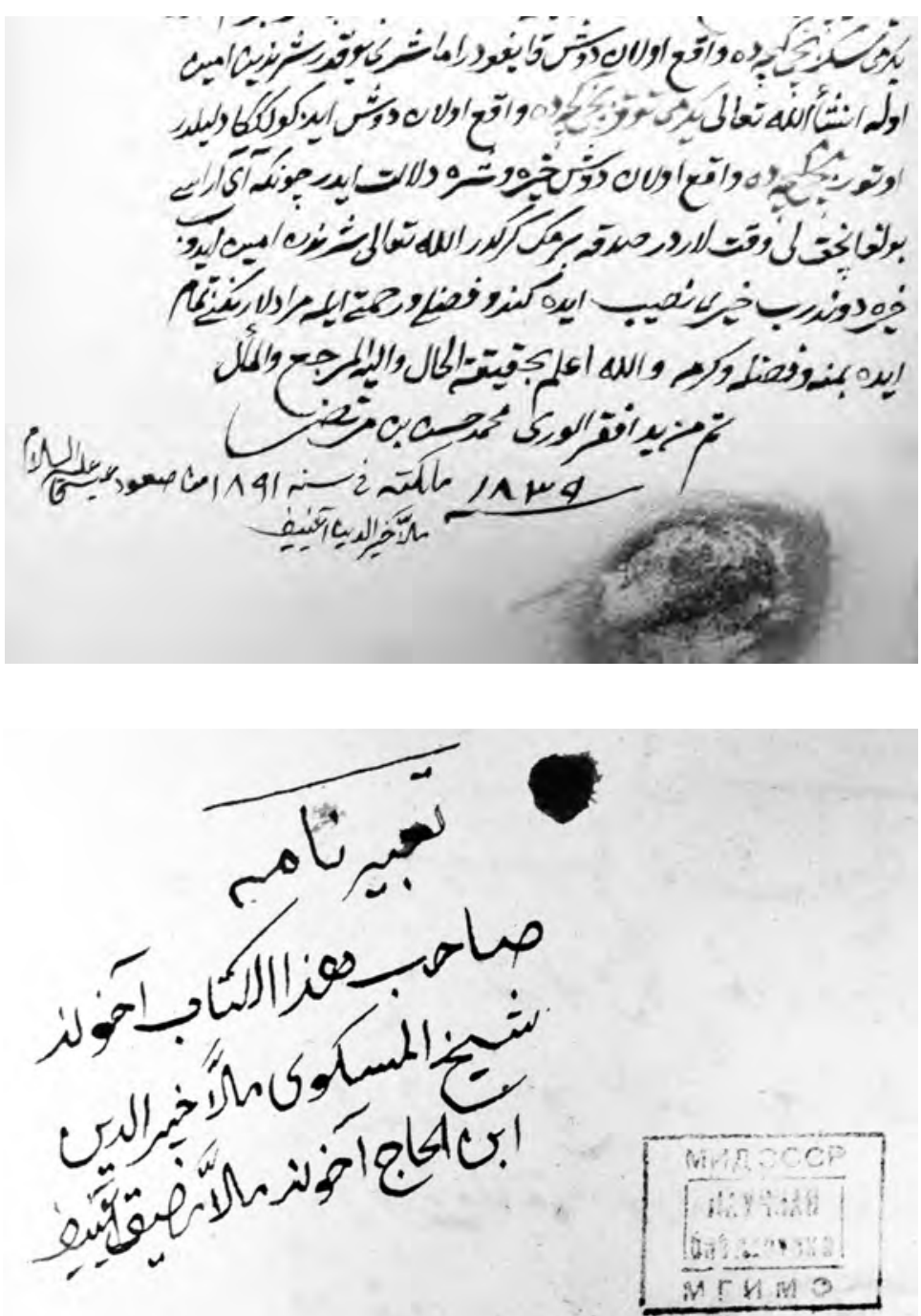
7. Кул Гали. «Кысса-и Юсуф» (МГИМО № 271). Переплет кожаный, не оригинальный, размер $16 \times 20$ см. Оригинальный переплет был бумажный из «мраморной» (эбру). Начало стандартное [Булгаков, 2002, с. 56-72, № 24-42].

В начале и конце к переплету подклеено по 3 листа. На форзаце (подклеенном) номер лазаревского описания 9751x. Почерк насх, текст в две колонки, 15 строк, хафизы, листы реставрированы поздней бумагой. На подплетенных листах в начале оказалось несколько интересных записей на русском и татарском языках, в том числе перечень детей Рафика Агеева:

«Татаринъ Зайнюддинъ Рафиковъ

Татаринъ Зайнулла Рафиковъ

Татаринъ Хайруддинъ Рафиковъ

Татарка Бибишарифя Рафикова

Газа китапъ Їюсовъ Хайруддинъ Рафикова

в татарскомъ диалекте писанъ».

На листе с автографами дата и место переписки: \AץF في شهر تزان. Особенно интересен лист рукописи с пометками Рафика б. Бекбулата о своем сыне Зайнетдине. Отец, исполненный гордостью за сына, пишет: «В конце четвертого года жизни мой сын Зайнетдин узнал азбуку, в пять лет, приехав в Казань, он читал суры хафтияка и мог читать уже "Книгу о Юсуфе"14. [Когда] ему исполнилось шесть лет в 1833 году мы приехали в Москву, в 1834 году в 7 лет он знал наизусть "Правила молитв" ( شروط الصلوة), “Кайданиев фикх" ( فقد كيدانى ) и “Завещание высочайшего имама" (وصية امكام اعظم). В 1835 году, когда ему исполнилось 8 лет, нашему служению имамом в Москве было уже 2 года....»15. Указанные сочинения - небольшие по объему популярные и ходовые

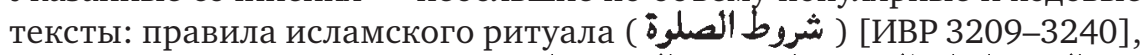
изложение ханафитского фикха (رسالة في انواع المشروعات وغير الدثروعات) Лутфаллаха Насафи ал-Фазил ал-Кайдани (ум. ок. 750/1349 г.) [ИВР 4570-4660] и религиозно-этические наставления Абу Ханифы [ [ИВР 3702-3724].

Ниже еще одна заметка: «в 1855 году мой сын Зайнетдин получил указ (اوقاز الدى) ), т. е. стал указным муллой. Ему тогда было 28 лет.

Рукописи МГИМО (У) МИД - это лишь часть библиотеки семьи московских имамов. Другая ее часть оказалась в Отделе рукописей РГБ. В разные годы туда поступило несколько рукописей, некогда бывших в семейной библиотеке. 

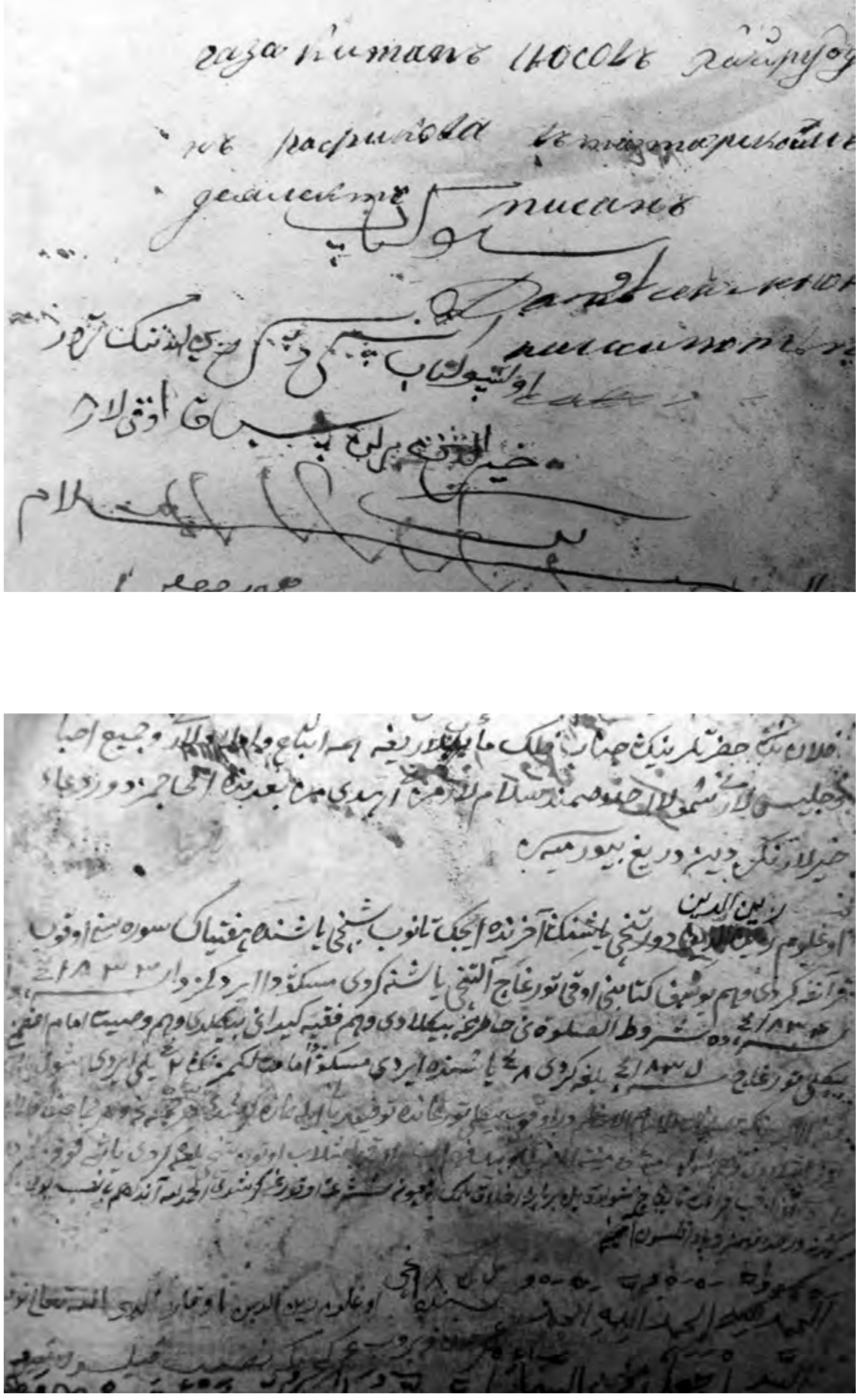


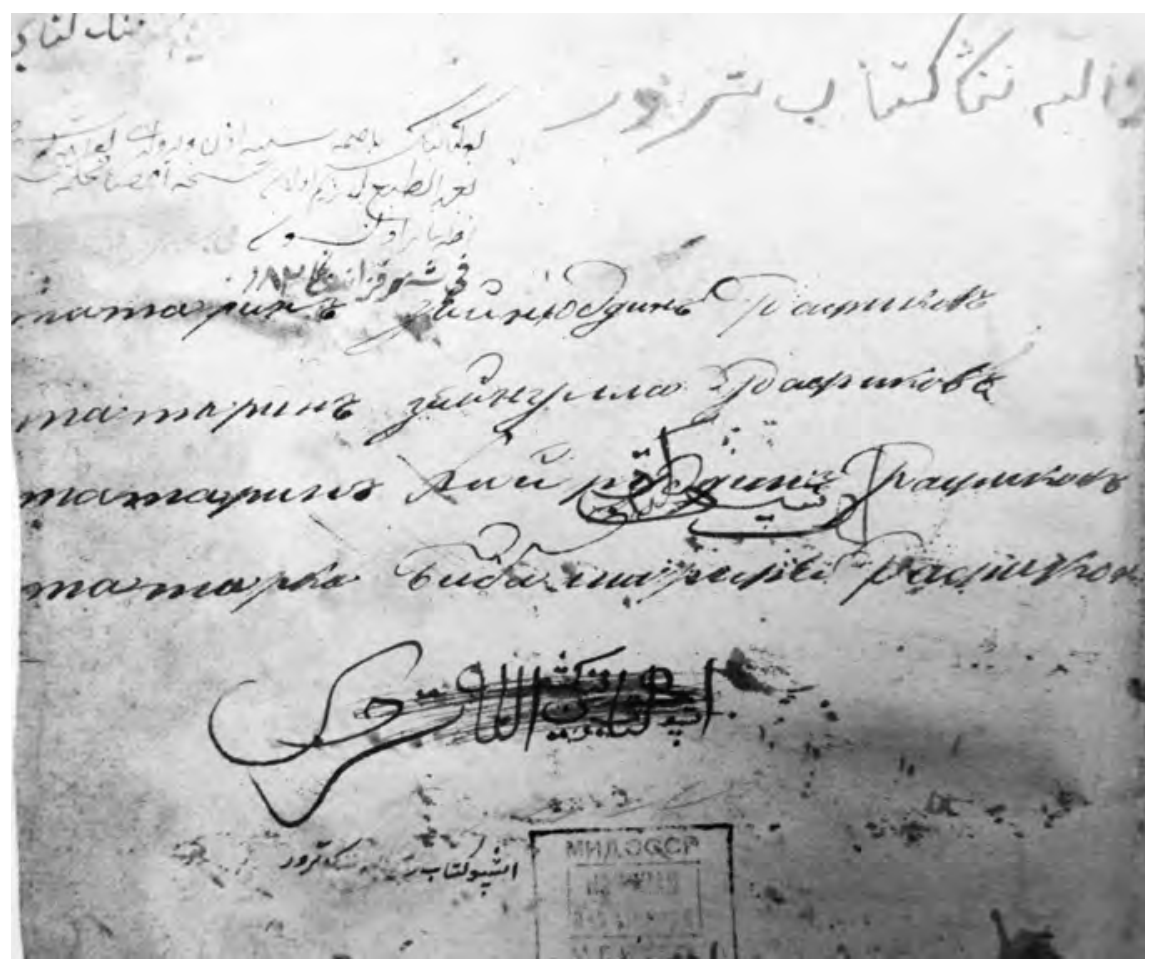

8. Ибн Кемаль-паша الاصلاح والايضاح (ОР РГБ, ф. 179. Музейные (арабские), № 37). Другие списки см.: [ИВР 4043-4046]. Рукопись поступила в 1941 г. от Кямиля Хасановича Булатова (продал Библиотеке 5 книг за 115 рублей), проживавшего по адресу Большая Татарская улица, дом 24, кв. 19. На верхней крышке приклеена бумажка с номером чернилами $\bigvee$ I. На нижнем обрезе коричневыми чернилами проставлено название сочинения. То же название повторено коричневыми чернилами и на приклеенной к корешку бумаге. Переплет картонный, крышки оклеены темно-коричневой кожей, корешок и края крышек - светлокоричневой. Размер 16×25,3 см. Блок слегка выступает по длинному обрезу. Крышки переплета, видимо, были переиспользованы и первоначально принадлежали другой рукописи. На форзацах - остатки шемсе (турундж со спутниками) черной кожи. Листы 1-6 чистые, подплетены позже. На л. 7-8 - стихи на тюрки. На л. 9 - фихрист. На л. $10-$ черный оттиск круглой печати с двуязычной легендой:

\section{Ахунъ Агъевъ أحون المسكوى رافيت [بن] ييكبولاط اغييف}

На л. 10об. после басмалы в орнаментальном прямоугольнике начало текста сочинения. Почерк насx, чернила черные, 23 строки на 
странице. Хафизы, оригинальная пагинация до л. 234. По современной пагинации - 255 листов. Листы 250-255 подплетены позже.

9. Толкование Корана (тафсир) с последовательным арабским текстом и переводом на тюрки (لسان تركى ) словию, - Абу ан-Наср Абд ан-Насир б. Ибрахим ал-Булгари ал-Курсави (по-татарски Габдуннасыр Курсави, ок. 1776-1812 гг.). ОР РГБ, ф. 180 (рукописи на языках народов СССР), № 5. Поступила в ОР РГБ 1962 г. На л. 291 (по библиотечной пагинации; л. 284 - по оригинальной) черный оттиск круглой печати с легендой: «Московск. Магометан. Имамъ Х.Р. Агъевъ. ملا خير الدين بن ملا رفيت اغييف». Переплет (21×31,5см) картонный, оклеен сильно потертой светло-коричневой кожей. На верхней крышке, которая отстает от блока, приклеен бумажный ярлык с номером (вероятно, порядковым в библиотечном собрании Агеевых): نومر 19. Бумага русская (штемпель). Текст в красной одинарной рамке $(12,5 \times 22$ см). Почерк насталик, коричневые чернила, коранические цитаты подчеркнуты красными чернилами, названия сур (с указанием места ниспослания - Мекки или Медины, а также количества айатов) также выполнены красными чернилами, 19 строк на странице, хафизы отсутствуют. На полях проставлено деление на джузы. Том заканчивается толкованием последних слов суры «ал-Исра'» («Перенос ночью»).

10. دلايل الخيرات وشوارق الانوار في ذكر الصلاة على النبى المختار (ОР РГБ. Ф.179. Музейные (арабские), № 119).

Переплет картонный, оклеен коричневой кожей с золотым тиснением (шемсе со спутниками) в османском стиле. Прекрасный многоцветный унван. Всего 94 листа. Бумага европейская (на л. 94 филигрань ACALARDON), размер $12,5 \times 18,5$ см. Текст в рамке $(8 \times 12,5 \mathrm{~cm})$ написан черными чернилами, почерк насх, 11 строк на странице, деление на строки подчеркнуто специальным значком, выполненным золотом; хафизы. На л. 13об-14 планы-изображения Мекки и Медины. Списки этого сочинения в мировых собраниях весьма многочисленны.

Год переписки рукописи: 1159 г.х. (1746/47 гг.). Экземпляр приобретен библиотекой в 1941 г. за 150 рублей у Мавтухи Хасановны Агеевой, проживавшей по адресу Большая Татарская, д. 20, кв. 12. Эта рукопись не российского происхождения. Однако судя по тому, что куплена она была у представительницы семьи московских имамов, скорее всего, была привезена из хаджжа кем-то из Агеевых.

11. Одна арабская рукопись из коллекции московских имамов оказалась ныне в собрании Института восточных рукописей РАН (бывший СПб Ф ИВ РАН). Это сочинение светского характера - антология по адабу. Шифр В 4523 [ИВР 9094]. Переплет картонный, оклеен коричневой материей, размер 17,5×21,5 cм. На верхней крышке проставлен на приклеенной бумажке номер: 123. Бумага русская (штемпель). Чернила коричневые, почерк насх, 18 строк на странице, текст 
в красной одинарной рамке $(9 \times 14$ см), последовательно проставлены хафизы. К сожалению, в рукописи утрачено начало (до страницы 465 по оригинальной пагинации). Сохранившиеся главы посвящены восхвалению смелости, порицанию трусости и т. д. Согласно колофону (с. 473), манускрипт переписан в Москве в среду 4 Джумада II 1286 г.х. (16 декабря 1859 г.). Переписчик Зайн ад-Дин б. ахунд мулла Рафик. В конце 13 чистых листов.

Исходя из изложенного можно сделать несколько выводов:

1. Думается, что и совокупная коллекция рукописей Агеевых из собрания библиотеки МГИМО (У) МИД, ОР РГБ и ИВР РАН далеко не полностью отражает состав библиотеки Агеевых. Нумерация неко-

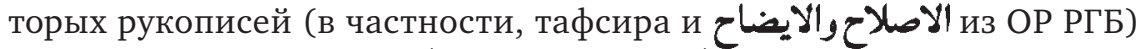
свидетельствует, что в собрании Агеевых было никак не менее 71 рукописной книги, а возможно, даже больше (ели учесть номер 123 на крышке переплета санкт-петербургской рукописи), из которых к настоящему времени нам известна лишь часть: 7 - в коллекции МГИМО (У) МИД, 3 - в ОР РГБ и 1 - в ИВР РАН. Уверен, что дальнейшие розыски рукописей из агеевской коллекции увенчаются успехом.

2. Часть рукописей (№ 1, 10) была Агеевыми куплена (скорее всего, в хаджже), часть переписывалась до переезда в Москву (1833 г.) в Казани (№ 7) и позже Москве (№ 3, 11).

3. Приписки к рукописи № 7 подтверждают, что переезд в Москву Рафика Агеева и начало его служения на новом месте состоялись в 1833 г. Несомненно казанское происхождение семьи.

4. Состав сохранившейся части библиотеки Агеевых любопытен. По языкам рукописи распределяются следующим образом: 8 - арабских, 2 - тюркские, 1 - смешанная (арабо-тюркская). Арабские рукописи представлены сочинениями по религии, философии (очень известный и популярный комментарий к Корану, догматика, правила совершения молитв, $и к x$, философия (логика), а также своего рода антологией по адабу, на тюркском — литература и гадания.

5. Наконец, можно сделать несколько заметок к генеалогии семьи московских имамов. Исходя из владельческих пометок и других данных, состав и родственные связи семьи выглядели примерно так (понятно, что новые источники могут уточнить наши представления о родственных связях). Рафик имел четырех сыновей: Хайретдин (род. ок. 1827 г.), Зайнетдин (родился, согласно пометке на рукописи МГИМО, в 1827 г.), Зайнулла (даты рождения его мы пока не знаем) и Хуснутдин (1838 г.р.) [Хайретдинов, 2008, с. 8] и как минимум одну дочь - Биби-Шерифя (1840 г.р.) от брака с супругой по имени Мегурбан. У Зайнетдина было два сына - Ахмет-Карим и Мухаммед-Карим, у Зайнуллы - один сын (Мухаммед). Хайретдин имел как минимум пятерых детей, о которых, впрочем, мало что известно: сыновей Ахмета и Гирея и дочерей Магиру, Рабигу и Зухру. 


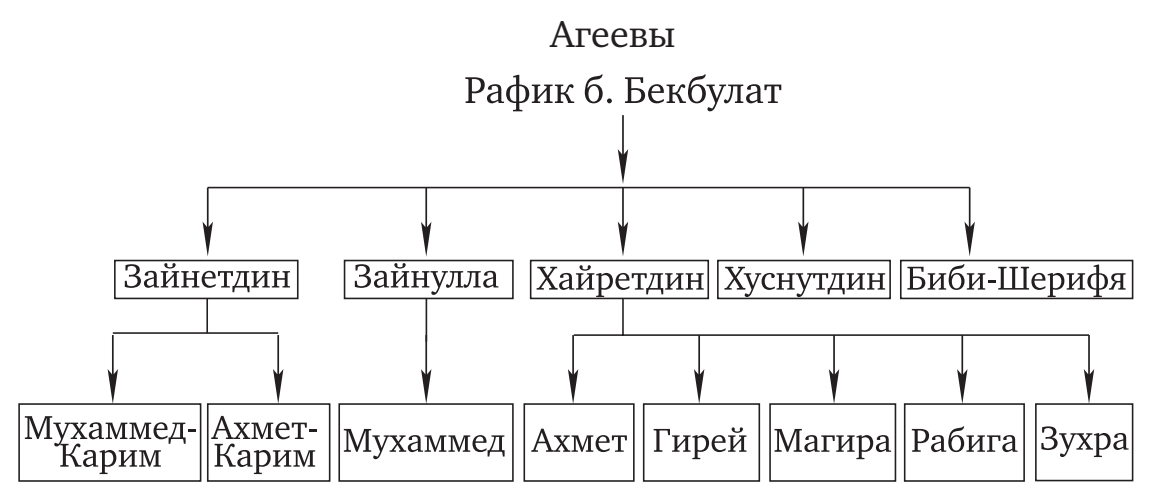

Выяснить, кто были мулла Абдулла («сын московского имама», перписчик рукописи № 5), некий Хасан и его дочь Мавтуха Агеевы, упомянутая как владелица манускрипта № 10, пока не представляется возможным $^{16}$. 


\section{Сокращения}

ИВР - Арабские рукописи Института востоковедения АН. Краткий каталог / Под ред. А.Б. Халидова. Ч. 1. М., 1986.

ОР РГБ - Отдел рукописей Российской государственной библиотеки

ЦИАМ - Центральный исторический архив Москвы

\section{Список источников и литературы}

Абдуллин, 2005 - Абдуллин Х. Мусульманское военное духовенство: состав, порядок избрания и утверждения (конец XVIII - XX в.) // Гасырлар Авазы / Эхо Веков. 2005. № 1.

Асадуллин, 2004 - Асадуллин Ф.А. Москва мусульманская. М., 2004.

Булгаков, 2002. - Булгаков Р.М. Описание восточных рукописей Института истории, языка и литературы. Ч. 1. Тюркские рукописи. Вып. 1. Произведения XII-XVIII веков. Уфа, 2002.

Дмитриева, 2002. - Дмитриева Л.В. Каталог тюркских рукописей Института востоковедения Российской академии наук. М., 2002.

Загидуллин, 2007 - Загидуллин И. Исламские институты в Российской империи. Мечети в европейской части России и Сибири. Казань, 2007.

Зайцев, 2004 - Зайцев И.В. Рецензия на книгу: Хайретдинов Д.З. Мусульманская община Москвы в XIV - начале XX века. Нижний Новгород, 2002 // Восток (Oriens), 2004. № 2. С. 188-192.

Зайцев, 2004а - Исламская рукописная книга из московских собраний / Islamic Manuscripts in Moscow Collections. Государственный исторический музей, 17 августа - 20 сентября 2004 г.: Каталог выставки / Авт.-сост. И.В. Зайцев. М., 2004.

Зайцев, 2005 - Зайцев И. В надежде на посмертное воздаяние... // Восточная коллекция. Весна 2005. № 1 (20). С. 134-141.

Зайцев, 2006 - Зайцев И.В. Из истории московской мусульманской общины в начале XVIII в.: дело о московском муэдзине (1712 г.) // Turcica et Ottomanica. Сборник статей в честь 70-летия М.С. Мейера. М., 2006. С. 59-63.

Зайцев, 2010 - Зайцев И.В. Московский имам в Оружейной палате. Новый документ о Хайретдине Агееве // Сборник статей в честь В.И. Шеремета. М., 2010 (в печати).

Идеатуллин, 1987 - Арабские рукописи по астрономии и математике в фондах Научной библиотеки им. Н.И. Лобачевского / Сост. М.Н. Идеатуллин. Казань, 1987.

Ислам, 2008 - Ислам в Москве: Энциклопедический словарь. Н. Новгород, 2008.

Исхаков, 2004 - Исхаков С. Российские мусульмане и революция (весна 1917 г. - лето 1918 г.). M., 2004. 
Маслов, 1992 - Маслов Ал. Древние урочища Замоскворечья: Крымский двор // Московский журнал. 1992. № 11.

Маслов, 1993а - Маслов Ал. Древние урочища Замоскворечья: Крымский брод // Московский журнал. 1993. № 1.

Маслов, 19936 - Маслов Ал. Древние урочища Замоскворечья: Крымский луг // Московский журнал. 1993. № 5.

Мустакимов, 2008 - Мустакимов И.А. Введение // Документы по истории Волго-Уральского региона XVI-XIX веков из древлехранилищ Турции. Казань, 2008.

Назаров, 2009 - Назаров Р.Р. Агеев Фахрель-Ислам Невмятуллович // Ислам в Центрально-Европейской части России: Энциклопедический словарь. Н. Новгород, 2009. С. 8-9.

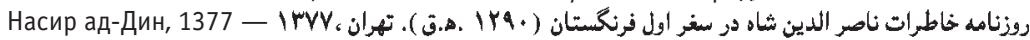

Хайретдинов, 2002 - Хайретдинов Д.3. Мусульманская община Москвы в XIV - начале XX века. Н. Новгород, 2002.

Хайретдинов, 2008 - Хайретдинов Д. Агеевы // Ислам в Москве: Энциклопедический словарь. Н. Новгород, 2008. 